Dulce Maria Cardoso - Ana Ille Horvat, University of Zagreb, Croatia

\title{
Vrapci na tlu
}

Princeze nikada ne umiru. Udaju se i žive sretno do kraja života.

"Ideja će mi sinuti kad se najmanje budem nadala", kaže Alice, "uvijek je tako. Neću očajavati."

Upravo sjedi na kauču držeći bilježnicu u rukama u koju je trenutak prije, velikim štampanim slovima na vrhu lista, upisala "ideje za Afonsov rođendan". Pažljivo je povukla pet strelica i svaku označila brojem. Poslije toga nije napisala više ništa. Ovo je već sedmi popis koji radi otkako je sjela.

Pogleda uprta prema dnevnom boravku, oko kažiprsta lijeve ruke mota plamen jarkoplave kose, kao u lutke.

"Kako se to smišlja neka ideja", upita se šapatom koji je uvježbala još u mladosti, "kako?"

Podere papir. Novi komadići poderanog papira padaju na hrpu pored kauča. Uzima novi list. Dok je list prazan, sve izgleda moguće.

"Nikada se ne dogodi ništa", jedva izusti, "može se dogoditi bilo što, a gotovo nikada se ne dogodi ništa."

Pogleda svoju sjenu na zidu. Stvarni pokreti nisu usklađeni s onima na zidu. Alice otvara i zatvara šaku i pažljivo promatra kašnjenje sjene.

Mlada, jako lijepa žena trči uskom, napuštenom ulicom. Posrće dok hoda u crnim lakiranim cipelama na visoku petu. Zbog uske suknje ne može trčati brže. Alice zabavljaju slike koje joj padaju na pamet. Noć je. Ulica prati visoke zidine. Žena je odjevena u kratki kaputić s tričetvrt rukavima i ljubičastu košulju na kojoj su prva tri gumba raskopčana. Koža joj je izrazito tamna. U crnim mrežastim čarapama noge joj izgledaju još dulje. Jako je umorna. Naslanja se na zid, teško dišući. Jarkocrvene su joj usne poprimile oblik lijepo oblikovanog srca. Spušta se uza zid i sjeda na tlo. Pokušava sjediti uspravno, s nogama u stranu, kako su nekada žene sjedile na piknicima. Pojavljuje se sjena na zidu. Lik koji se približava postaje sve veći i veći, sve dok više ne stane na 
zid. Sjena je u potpunosti prekrila pod. Žena nešto nejasno promrmlja. Preklinje. Njezine oči, velike i tamne djeluju prestrašeno. Na tlu, iz nekog kutka, cvrči cvrčak. Jako tiho.

Ako čujem cvrčke kako cvrče, mora da sam još uvijek dijete. Što se u međuvremenu dogodilo?

Alice gleda na sat na ruci, a zatim na sat na kuhinjskom ormaru. Taj sat nikada ne pokazuje isto vrijeme kao drugi. Uvijek se vidi razlika dvije-tri minute između tog sata i svih drugih satova.

Ponekad čak pet. Ipak, nikada više od pet.

Na kuhinjskom je satu bucmasti anđeo debelih nogu, sjedi na ljuljačci, koja satu služi kao njihalo. Alice je kupila anđeoski sat, kako ga zove, u jednom antikvarijatu, prve zime kad je došla u grad. Ulice su bile okupane blagim suncem. Alice je nosila plavu beretku koja joj je pristajala uz plave oči i svijetlu kosu. Muškarci su je gledali. Čak i neki koji su bili jako važni. Alice je znala što im je na pameti: uživala je u tome da je muškarci promatraju. Grad nije isti kao nekada. Da sada prođe ulicom s plavom beretkom, muškarci je ne bi gledali na isti način. Grad se promijenio.

Dok se divovska sjena miče, a svjetlo treperi, stvara se dojam da se, zapravo, miče žena na tlu. Negdje u daljini, čuje se sirena broda koji isplovljava. Žena pokušava ustati, odguruje se dlanovima o bijeli zid kako bi se uspravila. Nepravilno dišući otvara usta te tako izgleda još ranjivije. Nemoćno pada. Pod je sastavljen od bijelog i crnog kamenja u obliku zvijezda. Malenih zvijezda. Velikih zvijezda. Drugih još manjih. Brodska sirena pojačava maglu koja u koncentričnim krugovima obavija žućkasto svjetlo u daljini. Magla - gotovo se može dotaknuti, nalik je šećernoj vati.

"Svi bi satovi trebali pokazivati isto vrijeme", zaključi Alice.

Nikada nije pokušala ispraviti neusklađenost satova; nalik je neusklađenosti unutar i izvan njezine glave. To su tako beznačajne neusklađenosti. Zasigurno ih nitko ni ne primjećuje. Tri minute ne znače ništa. Baš ništa. Osim u filmovima, naravno.

Mnogo vremena provodi u najmanjoj i najmračnijoj prostoriji u podrumu gledajući filmove. Sjedi u zlatnom baršunastom naslonjaču koji je pripadao njezinu ocu. Naslonjač već neko vrijeme nije zlatan. Potamnio je i ostala je neka bezimena boja. Prljav. Nitko ne ulazi u tu prostoriju. Čak ni Eugénia koja je uvijek gotovo nečujna. Kao da stopalima ne dotiče tlo. Alice bi se zaklela da ne 
dotiče, da Eugénia hoda iznad tla. Kada su bile male, Eugéniina su stopala doticala tlo baš kao i svačija druga. I gotovo su uvijek bila bosa.

Nitko nije ni ulazio u očevu radnu sobu. Otac je uvijek radio. Otvorio bi novine, izravnao stranice, namjestio ih točno u razini očiju, zapalio cigaretu gotovo uvijek ostatkom prijašnje, kašljao, natočio viski, popio ga u jednom gutljaju, odložio čašu pored posude s ledom koju bi mijenjao svaka tri sata, ponovo ravnao stranice, ponovo punio čašu, palio novu cigaretu, kašljao - to je otac radio dok su majka i Alicine tete vezle ili slagale pasijans u dnevnom boravku s pogledom na dvorište u kojem su bili konji. Mnogo godina kasnije, kada je kuća išla na dražbu, službenik je popisao tri metalne alke na sjevernom zidu kuće. Alke su služile za vezanje konja i zahrđale su od nekorištenja. Za hladnijih bi dana majka i Alicine tete sjedile u drugoj prostoriji oko velikog stola s ognjem, koji je uvijek prekrivao stolnjak od zelenog filca, a na njemu je bio kraći, izvezeni stolnjak, bijele boje. Blagovaonica je gledala na vrt s paunovima. Isti je službenik opisao vrt kao omeđen prostor na južnoj strani, od četiristo i osamdeset kvadratnih metara.

No ni dnevni boravak, ni blagovaonica, kao ni bilo koja druga prostorija u kući, nisu mirisale na cigarete i papir kao očeva radna soba. Isto tako ni jednu ženu u kući nije mučio njegov kronični kašalj koji bi odjekivao po kući. Nijedna od njih nije prolijevala viski niti bi zaspala s cigaretom u ustima. Ma ne, kakva glupost, otac nikada ne zaspi, majka i Alicine tete uvijek bi je ispravljale, otac razmišlja, ima o mnogočemu razmišljati. Ponekad bi neka žena u obitelji govorila o opasnosti od požara, no neka druga bi je odmah ušutkala.

Alice je jako voljela slušati oca kako diše, potpuno drugačije od majke ili teta, tiho i jednostavno, kao što dišu ljudi s ulice. Posjete. Danas imamo posjete, rekli su joj, trebaš se lijepo ponašati. Gosti su rekli da je Alice baš dražesna, a to je uvijek dobro. Alice je uvijek htjela naučiti disati poput oca, zviždati dok se prsa nadimaju i spuštaju. Otac se od srca smijao kad mu je Alice to povjerila. Jako je voljela nasmijavati oca, no to se činilo još težim nego naučiti disati uz zviždanje.

"Osam minuta do ponoći", Alice pogleda na sat s anđelom. "Kako mi je mučno."

Da je rekla, kako se dosađujem, morala bi se osjećati drugačije, jer sve ima svoj naziv s nekim razlogom. 
Alice je okrivila dresing na salati koju je pojela za večeru. Tako je bilo jednostavnije.

"Ovaj dnevni boravak nema nijednog nedostatka", reče, protežući ruke dlanova okrenutih prema van i zijevne.

Sve se može oprostiti, ali estetske pogreške ne. Osim što su nepopravljive, još su i zarazne.

Za tjedan dana suprug joj slavi šezdeseti rođendan i Alice mu želi darovati jedinstven dar, o kojem još nema ni približnu ideju. Zato ponovo piše, na novom listu papira, ono o čemu je već razmišljala. Ovoga puta piše riječ Putovanje u loše nacrtan krug. Desno od kruga, povlači strelicu. Manjim slovima napiše Opcije i zatim otvori jednako nepravilnu kućicu. Ispred nje piše Pustinja. Dodaje, Luksuzno putovanje u pustinju.

Zaustavlja se na trenutak na onome što je upravo napisala. Lagano kima glavom. Križa. Polako. Bez ljutnje. Bezvoljno, kao da izvršava neku dužnost.

"Ako ništa drugo, barem još nisam trebala ništa ispravljati", kaže pobjedonosno.

Greške su samo dokaz da je trebala biti mudrija. Ništa se ne može naučiti iz grešaka, što se ne bi moglo naučiti bez njih.

Šezdeset godina. Kako smo samo tako ostarjeli?

Smiješi se. Odlučno niječe.

"Još uvijek izgledamo tako mladi", kaže otvorenih očiju, kao da se netko neće složiti s njom.

Sagne se i uzima s malog stolića ispred kauča čašu Ginger Alea. Ispije gutljaj. Pažljivo jezikom prijeđe preko usana s bljedoružičastim ružem, koji je stavila poslije večere, pazeći da ga ne pokvari. U tom se trenutku nasmiješi pred ogledalom. Željela je dokazati da još uvijek ima lijep osmijeh, da je još uvijek lijepa. Nije se udebljala s godinama, kao njene prijateljice.

Vani, kroz prozore koji ostakljuju dnevni boravak sa svih strana, vidi se rijeka; tekuća, treperava tama. Rijeci se može diviti s kauča na kojem Alice sjedi ili iz bilo kojeg drugog kuta dnevnog boravka, jer prostorija gleda upravo na nju.

"Rijeka je uvijek tako jednolična", njezin tugaljiv tok savršeno pristaje svijetlim uvojcima njezine 
kose kao u lutke, bljedoružičastom ružu, sandalama sa žutim vrpcama koje su odložene pored kauča, "kad bi barem obale rijeke..."

Često priča sama sa sobom. Vjerojatno je zato stekla naviku da ne dovršava rečenice. Ne zna se što je važnije za stvaranje neke navike, sâm čin ili potreba za njom.

Rijeka je tama, ništa manje sjajna od tame neba. Ništa manje treperava. Ništa manje dohvatljiva. U svakom slučaju tama.

Afonso mnogo putuje tako da putovanje ne bi bio nezaboravan poklon. I sada je jako daleko. Posao, kaže. Posao, to je ono što najčešće govori, ali izbivanja opravdava i drugim riječima. Alice mrzi kada joj suprug koristi riječ "poslovi", što smatra vrlo neukusnim. Nikada je nitko nije pitao zašto, niti joj je ikada itko protuslovio. No nije zbog toga takvo uvjerenje neuvjerljivije od drugih. "A da mu poklonim vrijeme, mnogo vremena?", izgovori uzbuđeno.

To bi moglo biti izvedivo. Nitko ne bi smio sažalijevati osamljene zbog besmislica koje im padaju na pamet.

"Kriva sam ja sama", ljutito kaže. "Što uopće mogu pokloniti čovjeku koji oduvijek ima sve?" Ginger Ale je pri kraju. Alice je nemirna. Stvari trebaju završiti kada ponestane volje za njima. Sada kada je Ginger Ale pri kraju, Alice osjeti žeđ. Da je još uvijek budna, Eugénia bi poslala neku od sluškinja ili bi ona otišla po drugi. Ne dopustiti da išta završi, jedna je od Eugéniinih zadaća. No Eugénia uvijek rano liježe. Noć služi za spavanje. I za grešnike. To je majka uvijek govorila kada bi je Alice molila da ostane još malo budna. Želiš li biti grešnica, pitala bi je majka. Ne, nije to željela. Želiš li ići u pakao, majka je bila uporna, a Alice je, sve uplašenija, ponovo odgovarala da ne želi. Majka bi se nasmiješila i prošla joj rukom kroz kosu. Lijepa djevojčice, lijepa djevojčice. Tim istim pokretima i tonom glasa tepala je psima koji su mahali repovima nakon šetnje. Lijep pas, lijep pas, govorila je majka tapšući cijeli čopor bijelim, njegovanim rukama, dok bi izlazila iz auta koji bi potom vozač parkirao u garaži i zatvorio mu krov bež boje. Rijetko su izlazili iz kuće.

Kada su bile male, Alice je lijegala puno ranije od Eugénie. Ići ćeš u pakao, govorila je Alice kada bi slučajno vidjela Eugéniu kako briše tanjure koje je njezina majka pomno prala u četvrtastom mramornom sudoperu, s bijelom pregačom oko struka. Eugénia joj nikada ne bi odgovorila i nikada 
joj se nije činila prestrašeno, zbog čega je Alice pomislila da Eugénia već poznaje pakao i da ga se ne boji.

Eugénia i Alice su se rodile u istoj kući, istog dana. S razlikom od osam sati i mjestom rođenja. Eugénia se rodila u jednoj sobi bez prozora, u sporednom dijelu kuće, u kojoj živi sva služinčad. Alice se rodila u sobi obasjanoj suncem koja je gledala na stabla kestena. Možda zbog toga nikada nisu postale prijateljice. Vjerojatno prijateljstvo zahtijeva neku veću podudarnost od samog mjesta rođenja.

Alice ustaje i odlazi po novu bocu Ginger Alea. Kada prođe pored sata s anđelom, na dan 31. kolovoza 1997, već je prošlo devetnaest minuta od dvije tisuće četiristo i četrdeset koliko posjeduje.

Na putu do kuhinje, cijelo vrijeme elegantno hodajući, glasno ponavlja sve ideje kojih se mogla sjetiti za Afonsov poklon. Ta buka, ta buka koju Alice jedva raspoznaje, to je zvonjava telefona. Preplaši se. Čudno da telefon zvoni u ovaj sat.

Ne može biti Afonso. Afonso nikada ne zove više puta u danu i zove uvijek u pristojno vrijeme, kao što je zvao danas, da kaže je li toplo ili hladno, je li bilo dobro ili loše. Alice ništa od toga nije važno. No jasno je da o nečemu moraju razgovarati. Pogotovo kada razgovaraju na daljinu.

Trči do telefona. Mora se javiti prije nego što zaključe da spava i prekinu. Ako se ne stigne javiti, provest će cijelu noć razmišljajući tko je to mogao biti. Neće se moći uvjeriti u to da je netko možda krivo nazvao. Telefon je na drugom kraju dnevnog boravka koji se sada čini još veći.

Manuel i Clara. Već dugo djeci nije potrebna. Da nisu Manuel ili Clara ili čak Afonso, koji je danas već zvao, da nije... Ne vjeruje da se radi o nekim lošim vijestima. Podiže slušalicu. Ruka joj pomalo drhti.

"Draga moja, dogodilo se nešto strašno."

Glas joj je poznat, no Alice ne uspijeva prepoznati o kome se radi. Prijateljica se mora predstaviti. "Draga moja", Alice je iskreno sretna, "tako mi je drago što te čujem, kako nisam prepoznala tvoj glas, o, draga moja, oprosti mi, ne obraćaj pažnju, tako sam rastresena da... " 
Princeza Diana umire.

Nije moguće.

Prijateljica opet ponavlja.

"To je tako tužno, nisam nikada čula ništa tužnije", doda Alice još tišim glasom.

Automobilska nesreća. Grozna automobilska nesreća.

Alice uzdahne. Prijateljica ne zvuči baš sigurno. Takva vijest zahtijeva točnost.

Išli su na večeru u hotel Ritz. Dodi je odmah umro. O, draga moja, to je tako grozno. Tako besmisleno grozno. Dodi joj je danas kupio zaručnički prsten. Zaprosio bi je kada stignu kući.

Eugénia uđe u dnevni boravak. Nosila je suknju i bluzu koje je imala za dana. Još nije legla ili se ponovo odjenula kada je čula telefon. Ili spava odjevena. Alice se nikada ne usudi ništa nagađati kada se radi o Eugénii.

"Čula sam telefon."

Alice joj ne odgovori.

"Krivi su fotografi koji su ih proganjali", prijateljica će. "Zbog njih su izgubili kontrolu i zabili se u stup."

"Nije ništa. Možeš ići spavati", dobaci Alice prekrivši slušalicu.

Eugénia se povuče. Kaže laku noć tek kad izađe iz prostorije. Alice joj ne odgovara.

"Mora da su fotografije strašne. Kažu da princeza neće preživjeti. Teško je ranjena. Baš mi ju je žao. Nikada nisam mislila da može biti sretna s Dodijem. Iz različitih su svjetova. Bilo je očito da nemaju zajedničku budućnost, no tko bi uopće mogao zamisliti ovakvu nesreću? I moja kćer se zaprepastila kad je čula ovu vijest. Upravo sam s njom razgovarala. I to baš sada kada dječacima počinje škola."

"Sve će biti dobro", Alice tješi prijateljicu, "izvući će se. Sigurna sam."

Bili su na odmoru na Dodijevoj jahti. 
"Znam", Alice će. "Znam."

Na naslovnici časopisa koji je Alice danas kupila, princeza sjedi na dasci visoko nad morem, u tirkiznom kupaćem kostimu. Rukama se drži za dasku, a noge joj vise u zraku. U jučerašnjem broju na palubi ljubi Dodija. Njegove ruke, tamne i dlakave, počivaju joj na bijelim leđima. Na njezinoj satenskoj koži, kakvu imaju samo princeze.

Sve su vidjela dva američka turista koja su bila tamo. Sigurna sam da će sutra govoriti o tome na televiziji. Sve je to tako strašno.

"Ne smije umrijeti", zaključi Alice. "Toliko fotografija."

Više ne sluša prijateljicu koja je pozdravlja, jer je kasno i obje moraju pokušati zaspati. lako će to, slažu se obje, biti jako teško. Gleda u kauč, prazan papir, praznu čašu Ginger Alea.

"Princeze ne umiru poslije ponoći", slabašnim će glasom. "Kakva bi to bila priča da ovako završi?" Ponovo sjedne na kauč. Više joj nije mučno. Priče, čak i one loše ispričane, uvijek su dobro društvo.

Kada netko pita gdje je nebo, odgovor je samo jedan. Kada netko pita gdje je pakao, odgovora je mnogo.

Dva gola tijela leže na krevetu. Jedan starac, Afonso i jedna djevojka, Sofia. Krevet je prostran, sa satenskom posteljinom. Vani je vruće, no u apartmanu 1715 klima je upaljena na najjače i hladno je. Leže u tišini.

Maloprije je Afonso pokušao započeti razgovor sa Sofiom.

"Nije li ovaj grad poseban? Meni je poseban od prvog dana. Još uvijek nisam otkrio zašto. Prvi puta sam ovdje došao... " 
"Znam", prekine ga Sofia, dosađujući se, "već si mi ispričao. Desetak puta. To je grad kao i svaki drugi", na trenutak zastane i napuše balon od gume za žvakanje. "Samo veći i prljaviji."

Afonso zašuti i prekriži ruke na prsima. Oduvijek je volio tako ležati, poput mrtvaca nad kojim se bdije. Sofia nije skidala pogleda sa stropa i cijelo je vrijeme rastezala gumu za žvakanje. Radila je balone koji su pucali uz dražesnu buku.

"Zašto si uvijek tako ljuta? Nije ti tako loše u životu."

"Što ti znaš o mom životu?"

"Ništa. Osim računa koje plaćam", odgovori Afonso ironično, "ne znam ništa."

"A, jasno, računi."

"I ovo", reče Afonso zagledan u Sofiino golo tijelo, "meni je to dovoljno. Ne trebam više ništa."

"Mogu li te nešto zamoliti? Možeš li malo šutjeti?", Sofia je glumila ljupkost. "Znam da je to teško, no možeš li barem pokušati, molim te?"

I tako su ležali, na leđima i gledali u strop. Dva tijela u velikom krevetu, u luksuznom apartmanu. Jedno od njih u položaju mrtvaca nad kojim će se bdjeti. Drugo s rukama ispruženima uz tijelo. Oboje goli, usprkos hladnoći od klime.

S druge strane vrata broj 1715 postarija žena usisava tepih sa šarenim cvjetovima. Druga, mlađa, gura kolica s ručnicima i propisno složenim bijelim plahtama, a treća još mlađa od druge, za njima gura druga metalna kolica, dosta veća od prvih, s kantom za vodu, dvije krpe, nekoliko spužvi i bocama s tekućinama raznih boja. Zelena tekućina služi za pranje poda, plava za kupaonski pribor, a ružičasta za stakla. Ljubičasta je za namještaj. Žućkasta je za sve i zato se gotovo nikada ne koristi. Žene nose bež uniforme i svjetloplave pregače. Oko vrata im vise male metalne pločice s ugraviranim imenima. Tepih s cvjetovima prigušuje korake brzih i marljivih žena. Prva u redu, Rosa Hazdra, ugleda poruku na vratima broj 1715 koja kaže "Ne smetati, vratite se kasnije, molim vas".

"Ubit ću Di Di, kunem se", kaže Rosa Hazdra. "Zbog nje sam propustila krštenje prvog unuka." 
Druga, ona koja gura kolica s ručnicima, Imola Cole, dođe do nje. Zatim i treća koja gura kolica sa sredstvima za čišćenje raznih boja, M. Coffman.

"Idi sada", kaže Imola Cole, "nisi ti kriva što joj se sin razbolio. To je bio tvoj slobodan dan. Davno si tražila. Di Di je to napravila namjerno. Idi sada, mi ćemo se snaći. Koliko će ljudi doći na krstitke?"

"Di Di je lukava. Zna s kim bi spavala. Ja spavam samo sa svojim mužem koji me vodi na bingo kada imam slobodan dan", odgovara Rosa Hazdra dižući glavu s poda.

"Trideset i dvije godine braka i on još uvijek ne zna da ne volim bingo."

"Ti voliš bingo. Kažeš da ne voliš samo da ga razljutiš. Koliko ljudi?", ustrajna je Imola Cole. "Šezdeset i tri. Da samo vidite tortu. Jučer smo išli po nju. S anđelom na vrhu. Raširenih krila kao da nas blagoslivlja. Jako lijepo."

"Od čega su krila?", pita M. Coffman.

"Toliko ljudi", začudi se Imola Cole. "Već dugo nisam bila na tako velikoj proslavi. I anđeo se jede?"

"Mislim da da. Donijet ću vam malo", Rosa Hazdra nogom isključi usisavač. "Kada krenem, proslava će već biti pri kraju. Već bih ja otišla, ali zvijer me ne voli. Samo traži izliku da me otpusti."

"Ja bih probala anđela", za sebe će M. Coffman.

"Ne budi luda. Kao da on ikad izlazi iz ureda", kaže Imola Cole, "zato je tako debeo." Prasne u smijeh i gurne Rosu Hazdru. "Hajde, idi sada. Valjda bi se svijet srušio da on digne guzicu s onog stolca."

"Ne znam što da radim", oklijeva Rosa Hazdra.

"Nemoj puno piti. Naporna si kad si mamurna." Imola Cole istrgne usisavač iz Rosinih ruku.

"Tko mi se javlja", Rosa Hazdra će uvrijeđeno, "jesam li ja možda povratila u koš za rublje?" 
"O moj Bože, to je zbilja bilo grozno", prizna Imola Cole, "nisam nikada bila tako pijana", nasmije se, "bila su to dobra vremena."

"Tebi", odgovori M. Coffman, "samo tebi, drugima to nije bilo smiješno. Hajde sada, Rosa. Proslava te neće čekati."

Rosa Hazdra protrlja ruke o bokove, kao da je neodlučna - na kraju pozdravi kolegice.

"Hajdemo se požuriti", reče M. Coffman Imoli Cole, "hoću ići gledati televiziju. Kažu da će danas govoriti princezini sinovi. Tako mi in je žao."

Vrata dizala nečujno se otvore i Rosa Hazdra se krene spuštati u podrum. Unutra je veliko ogledalo sa zlatnim okvirom u koje se Rosa Hazdra zagleda. Strah ju je otkaza, no ne želi propustiti krštenje prvog unuka. U ogledalu vidi zbunjeno lice i potraži strelicu koja označava katove. Na strelici nema znakova neodlučnosti.

"Konačno", kaže Sofia. "Mislila sam da nikada neće zašutjeti."

"Tko?", pita Afonso.

Sofia ne odgovori. Mržnju treba hraniti, a šutnja je dobar način za to. Ako oslabi, mržnja se pretvori u tugu koja stvara grč u želucu i ostavlja gorčinu u ustima. Ništa više. Za razliku od mržnje, tjeskoba nije zanimljiva. Tuga je poput tijesnih cipela. Ni jedno ni drugo ne ubija i ni jedno ni drugo ne stvara volju za ubijanjem.

"Gladna sam. Naručit ću nešto za pojesti."

"Ondje je sve što si maloprije naručila", Afonso pokaže prema stolu. "Rekla si da ti je to najdraži sok, a nisi ga ni taknula."

"Prevarila sam se. Otkada je to problem?", Sofia ispruži ruku prema njemu. "Dodaj mi jelovnik. Da vidim hoću li ovaj puta bolje naručiti."

"A dijeta?"

"Upravo je završila", provocira ga. "Ne želiš mi valjda reći da sam debela?" "Ni u ludilu, draga moja." 
Afonso joj pruži jelovnik s ukrasnim slovima. Sofia desnim kažiprstom prijeđe po meniju. Tu i tamo pomakne šiške da joj ne padaju u oči.

"Sladoled. Od vanilije, s preljevom od tople čokolade. I s posipom. I šampanjac, naravno. Bez šampanjca se ne može živjeti, nije li tako? Pogotovo u ovom tako posebnom gradu."

Uzme telefon i doda ga Afonsu. Sofia je lijepa, zapravo jako lijepa. Njezina ljepota očarala je Afonsa koji se ni ne trudi odoliti joj. Moć ljepote nije opasna.

"Naruči šampanjac i sladoled." I upozori ga ispruženim prstom, "nemoj zaboraviti posip."

Afonso posluša i vrati se u početni položaj. Nikada ne zna što bi radio sa Sofiom u trenucima nakon seksa. Praviti se da razgovaraju može biti jedna od mogućnosti. No Sofia, koja u tom trenutku podigne torbicu s poda, nikada ne želi razgovarati. Počne tražiti nešto po torbici. Kako joj kosa smeta, prebaci je na desnu stranu. I dalje kopa po torbici. U svakom njezinu pokretu dječje je tvrdoglavosti. Konačno pronađe cigarete i upaljač.

"Pušenje je zabranjeno", upozori je Afonso, izdižući se u sjedeći položaj i nasloni se na uzglavlje, presvučeno u bijelo, s gumbima razmještenima u rombovima.

"Nije li ovo najskuplji apartman?", upita Sofia, ni ne gledajući ga.

"Kako si tražila", odgovori Afonso nježno. "Tražila si sobu za nepušače. Rekla si da si prestala pušiti."

"Ponovo sam počela", Sofia zapali cigaretu i posegne za jednim od mnogih jastuka s volanima na krevetu i stavlja ga u krilo, "volim pušiti. Nikada neću biti poput tebe. Da budem iskrena, prezirem ljude poput tebe."

"A kakvi smo mi to ljudi?", upita Afonso, sad mu je već zabavno.

"Imate ružičasta pluća. Pazite na jetru, srce, mjehur, žuč, bubrege, kosti, bubnjiće, pazite na sve. Čini se da još uvijek niste shvatili da je život samo jedan veliki trošak. Tijela i snage. Trud da se poštedi tijelo je najbesmisleniji. Tijelo služi za korištenje i trošenje. Ne služi ni za što drugo. " Sjedne na koljena. Kroz kosu joj se naziru ukrućene bradavice. 


\section{"Želiš da smanjim klimu?"}

"Ne. Volim hladnoću. Stvara mi nelagodu."

"Voliš nelagodu?"

"Između ostaloga."

Sofia grize srcolike usne. Tako joj se usnice još više zasjaje. Afonso je poželi poljubiti. Sofia zapali cigaretu.

"Misliš da je ovo najskuplji apartman zbog svih ovih ukrasa?" Baca na pod jastuk koji je držala na krilu. "Ne. Najskuplji je jer se u njemu može raditi što god nam se prohtije. Zar ne služi novac tome?"

Sofia ustane i počne šetati s jednog kraja na drugi. I dalje je gola. Nagne se nad prozor i zagleda se u pravilnu mrežu grada. Prozor je jako velik, no ne može se otvoriti. To je jedan nevjerojatno čist ostakljeni zid. Gleda prema nebu koje joj se čini bliže nego sâm grad.

"Kada bi postojala samo jedna boja", glasno razmišlja Sofia, ne okrećući se prema Afonsu, "ljudi bi bili bolji. Smireniji. Kada bih mogla, živjela bih u svijetu samo jedne boje. Mogla bi to biti ova plava boja. Kako li im samo uspijeva održati ovo staklo tako čistim?"

"Mogu ti pružiti ovo", Afonso joj priđe i, ogrnuvši se kućnim ogrtačem, nježno joj stavi ruku na leđa, "možemo živjeti u svijetu kakvom poželiš."

Ona mu grubo odmakne ruku.

"S tobom, nikada. Nikada."

Afonso je snažno zgrabi za zapešće.

"Da, jasno. Već sam zaboravio. S tvojim zaručnikom", smije se, pomalo nervozan, "jasno, sa zaručnikom. Kad smo već kod toga", Afonso će, nježno joj milujući bedra, "vjerujem da si jako tužna što si morala na poslovni put." Prasne u smijeh i pogleda zaručnički prsten na Sofiinoj ruci. "Ne prestajem ga žaliti. Oduvijek sam žalio sve rogonje na ovom svijetu." 
"A ja žalim tebe. On mi ne mora plaćati da bude sa mnom. Da treba, ja bih plaćala njemu da budem s njim."

"Draga moja, sve ima svoju cijenu. A tvoja čak ni nije tako visoka. Prilično je razumna. Da samo znaš koliko sam morao plaćati za mnogo lošije od tebe. Ti si dosta isplativa, draga moja."

"Prestani me zvati draga. Mrzim kada pokušavaš biti drag."

Začuje se zvono. Sofia se okrene.

"A, moj sladoled." Pruži ruku prema Afonsu. "Dodaj mi kućni ogrtač."

Afonso krene prema vratima. Otključa bravu i otvori vrata. Da je ne vidi golu, Sofia bi morala otići u kupaonicu. No kako nije krenula na vrijeme, bilo je prekasno. Sada ne može hodati gola pred sobarom. Okrenuta je leđima prema vratima koja je Afonso otvorio. Sobar čeka dopuštenje da uđe.

Mladić, s velikim smeđim očima, okruglog lica, stoji pored metalnih kolica na kojima je na gornjoj polici čaša sa sladoledom prelivenim vrućom čokoladom, a na polici ispod šampanjac u posudi s ledom i dvije elegantne kristalne čaše. Sobar također ima metalnu pločicu na prsima, na svjetlosivoj odori s tamnosivim epoletama. Na njoj zaobljenim slovima piše Nate Garza.

Nate Garza vozi kolica i čeka dopuštenje da uđe. Kad kolicima prođe kroz vrata i nastavi dalje, podigne pogled i ugleda golu Sofiu. Pokuša prikriti iznenađenje, no Nate Garza nikada nije bio dobar glumac. Uznemiren, odveze kolica do stola u kutu. Počne sakupljati hranu koju je Sofia naručila prije nekoliko sati, a koju nije ni taknula.

"Ako možete potpisati račun", obrati se Afonsu, trudeći se ne gledati nagu Sofiu koja je i dalje nepomično stajala, okrenuta leđima. "Pretpostavljam da ovo mogu odnijeti", pokaže na jelo, "no ako želite, mogu i ostaviti, naravno."

Sofia pogleda prema maloj fotelji na koju je večer prije ostavila odjeću koju je nosila preko dana. Nije bilo teško dohvatiti crnu suknju i bluzu s ljubičastim cvjetovima. Crne lakirane cipele s jako visokom petom bile su nešto dalje, jedna kraj druge, kao u izlogu. Crne mrežaste čarape ležale su bačene na pod. Dovoljna bi joj bila samo dva koraka da dođe do odjeće. No odustaje od te 
namjere kada shvati da bi se morala odjenuti pred sobarom. Ne može ništa pred njim. Mora ostati što je moguće mirnija. Ako želi da Nate Garza na nju ne obrati pažnju, treba ga ignorirati.

"Idem po olovku", odgovori Afonso, ne gledajući što mu Nate Garza pruža. "Uživajte u pogledu. Prekrasna je, zar ne? Dobro, vi to viđate svaki dan. Mora da vam je dosta. Nema te ljepote koju navika ne ubije."

"Gosti uvijek uživaju", Nate Garza će nervozno, pokušavajući izvući smiješak. Izraz lica mu odaje sve veću nevjericu. "I ja, naravno."

"Zaklanjaš pogled gospodinu, draga", reče Afonso. "Nije pošteno, zar ne?", reče okrenuvši se ponovo Nateu. "Osim ako ne biste nju željeli promatrati, što je sasvim razumljivo. Kladim se da rijetko viđate tako lijepu ženu."

"Istina", odgovori Nate Garza, gotovo ispustivši tanjur iz ruke, "uistinu je jako lijepa."

Sofia stisne šake i zabije duge, tamnocrvene nokte u dlanove. Bol joj odvrati misli. Afonso se uputi prema noćnom ormariću. Uzme srebrno nalivpero u koje je sâm stavio tamnoplavu tintu prije nekoliko dana. Zatim otvori prvu ladicu i izvadi pozamašan snop novčanica. Krene prema Nateu Garzi koji stoji pored kolica na koja je već stavio sve što je bilo na stolu.

"Je li za vas", upita Afonso, polažući novac pred Natea Garzu, "ovo malo ili puno novaca?" Afonso potpiše račun. "Ako ikada budete u nedoumici oko izbora boje tinte u nalivperu, odlučite se za tamnoplavu. Nećete požaliti. Pitao sam vas, dakle, je li za vas ovo puno ili malo novaca?" Nate Garza sprema račun i približi ruku glavi, kao da će se počeškati. Zatim se sjeti propisnog držanja i odustane. Na trenutak ostane s rukom u zraku. Od neugode ne osjeća vlastitu ruku. "Tamnoplava", konačno pronađe odgovarajući pokret rukom. Lupne vrškom desnog kažiprsta nekoliko puta po čelu, "ostat će zauvijek zapamćeno. Hvala. Tamnoplava."

Afonso se nasmiješi.

"Moj je otac koristio istu boju. I djed također... moj pradjed je više volio... siguran sam da vas to ne zanima", podigne ponovo ruku u kojoj drži snop novčanica. 
"Vratimo se na moje pitanje", Afonso zakorači prema naprijed, kako bi se još približio Nateu Garzi koji tako naglo ustukne da padne, "za vas je to puno ili malo novaca?"

"Rekao sam da je puno za svakoga. No za mene je to uistinu puno novaca", odgovori nevoljko Nate Garza.

Sofia i dalje nepomično stoji. Gotovo da ne diše. Usmjerena je na bol koji osjeća od noktiju zabodenih u dlanove. U misli joj navire bujica nepovezanih riječi. Čini se kao da ju je činjenica da stoji naga pred sobarom odvela u neki nadrealni svijet iz kojega nikada više neće izaći. Kad bi barem mogla razmišljati o nečemu drugome. Još jače zabije nokte u dlanove. Na kraju se sjeti da se sladoled topi i da će morati tražiti drugi.

"Imam za vas jednu ponudu", kaže Afonso Nateu Garzi smješkajući se, "jednu primamljivu ponudu".

Nate Garza pokuša izmisliti radnje koje mu dopuštaju da gleda u pod. Ne gleda u snop novčanica, ni u Sofiu, no ni tako se ne osjeća sigurnim.

"Pogledajte je", naredi mu Afonso. Zatim nastavi gotovo nježnim glasom. "Draga, okreni se kako bi ovaj srećković mogao uživati u tvojoj izvanrednoj ljepoti." Sofia se ne pomakne, a Afonso se opet obrati Nateu. "Gledajte, ovako ćemo, idite do nje i gledajte koliko vas je volja. Niste gej, je li tako?" "Ne, gospodine", Nate Garza požuri s odgovorom.

"Odlično. I nadam se da se volite, reći ću, jebati, iako je ružno tako govoriti pred damom, nadam se da volite imati snošaj, je li tako?"

Nate Garza ne zna što da odgovori. Sve je zbunjeniji.

"Ne bih želio imati problema", jedva govori, "imam ženu i djecu. Treba mi ovaj posao."

"Reći volite li imati snošaj ne može vam donijeti probleme. Osim ako niste nastrani. No dobro, pustimo to." Afonso se nasmiješi. Činilo se da se sve više zabavlja. "Sve što kažete u ovoj sobi, ostat će u ovoj sobi." Afonso potapša Natea Garzu po ramenu. "Mislite na to kako vam se danas sreća nasmiješila. Priđite joj. Ne bojte se, ne grize."

Kako je Nate Garza i dalje nepomično stajao, Afonso ga uhvati za ruku i odvede do Sofie. Nije 
učinio nijedan nagao ni nesiguran pokret. Sve se odvijalo kao da su on i Nate Garza uvježbavali pokrete desetak puta.

"Slobodno pogledajte", Afonso se u tišini povuče u drugi kraj sobe, "uzmite vremena koliko vam treba."

Nate Garza gleda prema Sofii, no samo razmišlja o tome kako se jako znoji i kako će mu uniforma biti umrljana znojem. I kako mu je lice sigurno crveno i znojno. Dok razmišlja o tome, samo se još više zacrveni.

Vidjevši Natea Garzu tako prestrašenoga, Sofia se sažali nad njim. Kaže mu tiho:

"Sve je to šala. Ne boj se."

Nate Garza grubo odgovori, kao da ga je netko opalio bičem.

"Ne bojim se ničega", odgovori, vidno uvrijeđen.

Na drugom kraju prostorije Afonso se grohotom smijao. Sofia ga nikada nije vidjela da se tako smije.

"Što ti ovo treba?", upita ga Sofia.

Afonso priđe Sofii i zgrabi je za bradu. Podigne joj glavu sve dok joj oči ne dođu u razinu njegovih.

"Draga moja, ako ne možemo odlučivati o onome što imamo, što će nam to onda uopće?"

Sofia se udalji od prozora. Više joj nije neugodno proći pored Natea Garze. Uzme usku suknju i obuče je preko glave. Pokreti su joj spori. Obuče ljubičastu bluzu na cvjetove. Polagano zakopča gumbe. Zatim kratak kaputić s tričetvrt rukavima. Obuje lakirane cipele na petu. Tako odjevena izgleda još krhkije nego gola. Dođe do kreveta. Nesigurno hoda na visokim petama. Iz torbice izvadi cigaretu i zapali je. S upaljačem u ruci, sjedne na krevet. Puši dugačke i tanke cigarete. Sofii inače dobro stoji cigareta u ruci. Možda zato što puši kada joj je dosadno, što sada nije slučaj. $U$ očaju se baca na krevet s cigaretom u ustima.

Nema na nebu ni komadića koji ne pripada istom plavetnilu. Sofia je uvjerena da će, ako pogleda u daljinu, pronaći komadić bijelog oblaka ili komadić drugog plavetnila i uspjeti ušutkati sve oko sebe. 
Ili ugledati pticu. Ne. Nije baš moguće da ptica leti na toj visini. Možda avion. Da, avion. Avioni stalno lete s jedne strane na drugu.

Afonso ponovo priđe Nateu Garzi. Svaki njegov pokret uznemiruje Sofiu. Poput ovoga dok polaže dlakavu ruku na sivu uniformu Natea Garze ili bilo koji drugi koji bi mogao učiniti. No nisu to samo pokreti. Sve na njemu uznemiruje Sofiu. Sijede obrve koje je dao urediti. Ljepljivi jezik kojim ovlaš dodiruje zube dok govori. Velike nosnice koje se lagano šire dok diše. Smiješak koji mu zatvara oči. Sofia zna napamet svaki dio Afonsova tijela. Nitko ne uspijeva mrziti bez truda. Osobu koju želimo mrziti trebamo dobro poznavati. Za mržnju je potrebno više iskustva i rutine, nego za ljubav.

"Onda, što kažete? To je sigurno najljepša žena koju ste u životu vidjeli."

Nate Garza nespretno protrlja ruke i sakrije se iza metalnih kolica.

"Da, tako je", odgovori, ne skidajući pogled sa stola na kojem se topi sladoled, "uistinu je jako lijepa."

"Govorite glasnije", Afonso se nasloni na prozor, a zbog svjetla je izgledalo kao da je na pozornici. "Znate da je jačina glasa jako važna. Čovjeka kojega ne čuju, ne poštuju. Ponudit ću vam nešto vrlo jednostavno. Tražim od vas da birate. Između čega?", Afonso se nasmiješi, otkrivajući izrazito bijele zube. "Između nje i svog ovog novca." Podigne snop novčanica, "jedna noć s njom ili sav ovaj novac."

Nate Garza pogleda Afonsa pa Sofiu, koja se pravi da se ništa ne događa.

"Ako vam treba vremena da razmislite", Afonso će očinskim glasom, "samo izvolite. Ne žuri nam se."

Sofia letimice pogleda Natea Garzu. Poželi da on kaže, ne želim ništa, ni vaš novac, ni vašu kurvu. Sobar je ne bi drugačije nazvao. Ni ne može je drugačije nazvati.

No Nate Garza i dalje šuti. Neće biti tako hrabar. Njegovu hrabru reakciju Afonso nije ni predvidio. Heroj Nate Garza ne bi se znojio kao što se ovaj znoji. Niti bi mu toliko drhtale ruke.

"Šalite se sa mnom?", upita Nate Garza. "To je za one emisije na televiziji, nije li tako?" "Odabirom se stječe pravo na isplatu. To je sve." 
Nate Garza još jednom pogleda Sofiu. Zatim Afonsa. Svjetlosiva mu je uniforma sada potpuno mokra ispod pazuha i na leđima. I na trbuhu mu se počinje nazirati znoj.

"Jeste li odlučili?", upita Afonso. Naste Graza ga pokušava gledati u oči, no spušta pogled. Kima glavom u znak potvrde.

Afonso kreće prema Nateu Garzi koji uzmiče. Imun na užas koji je izazvao u Nateu Garzi, povlači prema sebi metalna kolica. Saginje se i iz posude s ledom uzima bocu šampanjca i čaše.

"Predlažem zdravicu za čovjeka koji je prihvatio odabir. Čin odabira je najvažniji. Nije važno je li odabir ispravan ili ne", okrene se prema Sofii i upita, "nije li tako, draga moja? Dođi ovamo. Nazdravit ćemo čovjeku koji je prihvatio izazov. Dođi, draga."

Sofia je već odustala od neba. Plač joj zastane u grlu sve dok ne nadjača bol koji osjeća od noktiju zabijenih u dlanove. Poželi da joj taj bol zaustavi dah. Kad bi barem umrla, ovdje, u ovom luksuznom apartmanu, pred ovom dvojicom muškaraca koji pripremaju zdravicu. Ljudi poput nje zaslužuju bolnu i tužnu smrt.

Najednom se začuje protupožarni alarm. Nate Garza istog trena spusti čašu.

"Sve je u redu", kaže Afosno. "Dakle, recite što ste odlučili."

Nate Garza pogleda Sofiu pa Afonsa i na kraju spusti pogled i pokaže na novac. Afonso mu pokretom ruke da znak da progovori. Nate Garza pročisti glas uz zvuk koji je djelovao neobično glasno u danim okolnostima.

"Novac", Nate Garza podigne pogled i gotovo prkosno ponovi, "odabirem novac".

Sofia se ne obazre na riječi koje je Nate Garza upravo izgovorio. Afonso se pobjedonosno nasmiješi.

"Kako želite", kaže. "Kao što sam rekao, trebate samo odabrati." Uzme novac i preda mu ga. "Uzmite, vaš je."

Nate Graza u nevjerici uzme novac. Ne skida smiješak s lica, sav u nevjerici. Alarm i dalje zvoni.

"Da sam na tvom mjestu, spremila bih novac. Ne bi bilo dobro da te zateknu sa svim tim 
novčanicama u rukama. Kako bi to opravdao?", upita Sofia ustajući s kreveta i hodajući prema njemu.

Nate Garza brzo podijeli novac u dva snopa i spremi ga u džepove. Izgledalo je kao da ga je upravo ukrao. Pogleda Sofiu koja je osjećala iskreno gađenje prema njegovoj pohlepi, prema svemu što ju je na njemu podsjećalo na nju samu.

"Rekao bih istinu. Rekao bih da su mi ga dali", Nate Garza se okrene prema Sofii.

"A tko bi u to povjerovao? Dok si k tome u takvoj uniformi", pokaže na mrlje od znoja. "Misliš da bi ti netko povjerovao?"

Nate Garza je sve uplašeniji. Alarm ne prestaje zvoniti.

"Što čekate?", upita Afonso. "Idite sada. Kao što sam rekao, danas vam je sretan dan."

Nate Garza je htio reći da ne vjeruje ni Afonsu ni Sofii, no istina zahtijeva moral, makar i zrnce.

Zbog toga i dalje stoji kao kip, neodlučan je i prestrašen. Lice mu više nije debelo, čak je mršavo i duguljasto.

"Idite sada, čovječe", ponovi Afonso.

"Još jednom, odluka je tvoja", doda Sofia, posegne žličicom prema gotovo rastopljenom sladoledu i prinese ga ustima.

"Obožavam ovaj posip. Kao da jedem dugu."

Nate Garza bijesno pogleda Sofiu. Nespretnim pokretom izvadi novac iz džepova i baci ga na krevet. Krene prema metalnim kolicima i pogura ih prema vratima. U želji da što prije izađe iz sobe, gotovo posrće. Afonso odmahne glavom. Priđe Sofii.

"Ne razumijem takve ljude."

Sofia krene prema krevetu i ponovo se strovali na njega. Afonso se baca na nju. Novac je rasut po krevetu.

"Kao što vidiš, draga moja, tvoja je ljepota važna samo onome tko je zna cijeniti. A to ne znaju mnogi. Želiš li ići u kupnju?" 
"Podučavaj svoju ženu i djecu", reče Sofia, gledajući ga mirno.

"Jesu li zbog tvoje slatkorječivosti postali takvi kakvi jesu?"

Čovjek koji je upravo izašao iz dizala, nosi pomno skrojeno, skupo odijelo i nema pločicu s imenom na prsima. S hodnika Imola Cole i M. Coffman vide kako kuca na vrata apartmana 1715.

"Oprostite", kaže mu Afonso, "zaboravio sam da sam tražio sobu za nepušače."

Čovjek se osvrne po sobi. Ugleda Sofiu na krevetu i novac rasut uokolo.

"Ovaj hotel ima svoja pravila i svi ih gosti moraju poštovati, čak i najvažniji kao što ste vi", govori čovjek ne skidajući smiješak s lica. "Nepoštivanje pravila je nepoštivanje drugih gostiju, a siguran sam da vam to nije namjera", čovjek pokuša ući, no Afonso mu ne dopusti. "Molim vas da ovdje više ne pušite. Ako želite, naći ćemo vam sobu za pušače."

Imola Cole i M. Coffman prođu pored čovjeka ispred apartmana 1715 nekoliko trenutaka nakon što Afonso kaže da će platiti koliko god treba i pristojno zatvori vrata.

"Ne bi li trebale već biti na katu ispod?", upita uzrujano. "Gdje vam je kolegica?"

Imola Cole i M. Coffman nespretno se nasmiješe. Imola Cole kaže:

"Unuk joj se krsti. Prvi unuk. Mi ćemo je zamijeniti."

"Recite joj da se više ne mora vraćati", odgovori i ode.

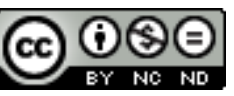

Creative Commons Attribution-NonCommercial-NoDerivatives 4.0 International License 